\title{
Baclofen and 2-hydroxysaclofen modify acute hypolocomotive and antinociceptive effects of nicotine
}

Andrés P. Varani ${ }^{\mathrm{a}}$, Ester Aso ${ }^{\mathrm{b} \#}$, Rafael Maldonado ${ }^{\mathrm{b}}$, Graciela N. Balerio ${ }^{\mathrm{ac}^{*}}$

${ }^{a}$ Instituto de Investigaciones Farmacológicas (CONICET), Junín $9565^{\circ}$ Piso, Buenos Aires C1113AAD, Argentina.

${ }^{b}$ Laboratori de Neurofarmacologia, Facultat de Ciències de la Salut i de la Vida, Universitat Pompeu Fabra, C/Dr. Aiguader, 88, 08003 Barcelona, Spain.

${ }^{c}$ Cátedra de Farmacología, Facultad de Farmacia y Bioquímica, Universidad de Buenos Aires, Junín $9565^{\circ}$ Piso, Buenos Aires C1113AAD, Argentina.

${ }^{\text {\#} P r e s e n t ~ a d d r e s s: ~ I n s t i t u t ~ d e ~ N e u r o p a t o l o g i a, ~ S e r v e i ~ d ' A n a t o m i a ~ P a t o l o ̀ i c a, ~ I D I B E L L-~}$ Hospital Universitari de Bellvitge, L'Hospitalet de Llobregat, Spain

*Corresponding author. Dr. Graciela N. Balerio. Instituto de Investigaciones Farmacológicas (CONICET). Cátedra de Farmacología, Facultad de Farmacia y Bioquímica, Universidad de Buenos Aires, Junín $9565^{\circ}$ Piso, Buenos Aires C1113AAD, Argentina Tel.: +54-11-4961-5949. E-mail address: gbalerio@ffyb.uba.ar 


\begin{abstract}
The aim of the present study was to evaluate the possible involvement of $\mathrm{GABA}_{\mathrm{B}}$ receptors in nicotine-induced hypolocomotion and antinociceptive effects in mice. Animals were exposed to nicotine only once. Acute nicotine hydrogen tartrate salt (3 $\mathrm{mg} / \mathrm{kg}$; subcutaneous, s.c.) administration induced hypolocomotion and antinociceptive responses in the tail-immersion and the hot-plate tests. The effects of pretreatment with either the $\mathrm{GABA}_{\mathrm{B}}$ receptor agonist baclofen $(1,2$ and $3 \mathrm{mg} / \mathrm{kg}$; intraperitoneal, i.p.) or $\mathrm{GABA}_{\mathrm{B}}$ receptor antagonist 2-hydroxysaclofen $(0.25,0.5$ and $1 \mathrm{mg} / \mathrm{kg}$; i.p.) were evaluated on these behavioral nicotine responses. The $\mathrm{GABA}_{\mathrm{B}}$ receptor agonist, baclofen (3 mg/kg, i.p.) abolished nicotine-induced antinociceptive effects in the tailimmersion and the hot-plate tests, but did not modify nicotine-induced hypolocomotion. In addition, the $\mathrm{GABA}_{\mathrm{B}}$ receptor antagonist, 2-hydroxysaclofen $(1 \mathrm{mg} / \mathrm{kg}$, i.p.) increased nicotine-induced antinociceptive effects in the tail-immersion and the hotplate tests, and abolished nicotine-induced hypolocomotion. The present results shed light that the $\mathrm{GABA}_{\mathrm{B}}$ receptor has an important role in mediating specific acute nicotine responses; such as hypolocomotion and antinociception in mice.
\end{abstract}

Keywords: nicotine; baclofen; 2-hydroxysaclofen; GABA ${ }_{B}$ receptors; nociception; locomotion. 


\section{Introduction}

Nicotine is the main active ingredient in tobacco smoke and plays a major role in tobacco addiction (Dani and Balfour 2011). In rodents, nicotine produces several behavioural responses, including changes in locomotion, nociception, anxiety, learning, memory, rewarding effects and physical dependence (Berrendero et al. 2010).

Regarding locomotion and nociception, nicotine induced hypolocomotion (Berrendero et al. 2005; Castañe et al. 2002; Varani et al. 2012) and antinociceptive responses in the tail-immersion and the hot-plate test (Galeote et al. 2008; Trigo et al. 2009; Varani et al. 2012) in mice. The pharmacological effects of nicotine are mediated by the activation of nicotinic acetylcholine receptors, which are widely distributed through the central nervous system. Neuronal nicotinic acetylcholine receptors are pentameric ligand-gated ion channels, composed of either homomeric or heteromeric combinations of different subunits $\left(\alpha_{2}-\alpha_{10}\right.$ and $\left.\beta_{2}-\beta_{4}\right)$, which generates a wide diversity of receptors with various electrical and binding properties (Millar and Gotti, 2009). Nicotine promotes the release of diverse neurotransmitters in the central nervous system, such as glutamate, $\gamma$ aminobutyric acid (GABA), acetylcholine, dopamine, norepinephrine and serotonin (Picciotto and Corrigall 2002). We have now focused our interest on GABA, the major inhibitory neurotransmitter in the mammalian central nervous system. This amino acid acts on two classes of receptors: ionotropic $\mathrm{GABA}_{\mathrm{A}}$ and $\mathrm{GABA}_{\mathrm{C}}$, and metabotropic $\mathrm{GABA}_{\mathrm{B}}$ receptors. The $\mathrm{GABA}_{\mathrm{A}}$ and $\mathrm{GABA}_{\mathrm{C}}$ receptors are located mostly postsynaptically (Barnard et al. 1998), while $\mathrm{GABA}_{\mathrm{B}}$ receptors are located both pre and postsynaptically (Bowery et al. 2002). The $\mathrm{GABA}_{\mathrm{B}}$ receptors are coupled to $\mathrm{G}$ proteins and form a heterodimer of $\mathrm{GABA}_{\mathrm{B} 1}$ and $\mathrm{GABA}_{\mathrm{B} 2}$ subunits, both necessary for $\mathrm{GABA}_{\mathrm{B}}$ receptors to be functionally active (Marshall et al. 1999). 
$\mathrm{GABA}_{\mathrm{B}}$ receptors have been reported to modulate several behavioral responses of nicotine related to its addictive properties (Corrigal et al. 2000; Cousins et al. 2002; Fattore et al. 2002, 2009; Le Foll et al. 2008; Paterson et al. 2004; Paterson, 2009; Varani et al. 2011, 2012, 2014; Varani and Balerio 2012). However, the possible effects that could result from the pharmacological activation or blockade of these receptors on the hypolocomotion and antinociception induced by nicotine remain to be clarified. In this study, these two behavioral responses induced by acute nicotine administration were evaluated in mice pretreated with baclofen $\left(\mathrm{GABA}_{\mathrm{B}}\right.$ receptor agonist) or 2hydroxysaclofen $\left(\mathrm{GABA}_{\mathrm{B}}\right.$ receptor antagonist). Acute nicotine locomotor effects were measured in activity boxes and nicotine antinociceptive responses in the tail-immersion and the hot-plate test.

\section{Materials and methods}

\subsection{Animals}

Male Swiss Webster mice obtained from Bioterio Central (Facultad de Farmacia y Bioquímica, Universidad de Buenos Aires, Argentina) and Charles River (France) weighing 22-24 g were housed five per cage, acclimated to the laboratory conditions according to local regulation (SENASA 2002) (12-h light: 12 -h dark cycle, $21 \pm 0.5^{\circ} \mathrm{C}$ room temperature, $65 \pm 10 \%$ humidity) and manipulated for three days prior to the experiment for handling habituation. Food and water were available ad libitum. Behavioral tests and animal care were conducted in accordance with the standard ethical guidelines (European Community Guidelines on the Care and Use of Laboratory Animals 86/609/EEC and 2001-486/EEC) and approved by the local ethical committee: CICUAL (Institutional Committee for Care and Use of Laboratory Animals, Facultad 
de Farmacia y Bioquímica, Universidad de Buenos Aires, Argentina). All experiments were performed with the investigators being blind to the treatment conditions.

\subsection{Drugs}

(-)-Nicotine hydrogen tartrate salt ([-]-1-methyl-2-[3-pyridil]pyrrolidine) (Sigma Chemical Co., Buenos Aires, Argentina), ( \pm ) baclofen (Novartis Argentina S.A.) and 2-hydroxysaclofen (Sigma Chemical Co., Buenos Aires, Argentina) were used in this study. Nicotine and baclofen were dissolved in isotonic $(\mathrm{NaCl} 0.9 \%)$ saline solution, and 2-hydroxysaclofen was dissolved in isotonic (5\%) glucose solution immediately before use.

2-hydroxysaclofen $(0.25,0.5$ and $1 \mathrm{mg} / \mathrm{kg})$ and baclofen $(1,2$ and $3 \mathrm{mg} / \mathrm{kg})$ were administered intraperitoneally (i.p.) 10 and $45 \mathrm{~min}$ before nicotine $(3 \mathrm{mg} / \mathrm{kg})$, respectively. The doses of 2-hydroxysaclofen and baclofen were based on a previous study from our laboratory (Varani and Balerio, 2012). The dose of nicotine hydrogen tartrate salt (3 mg/kg; subcutaneous, s.c.) was chosen taking into account our previous results (Castañé et al. 2002) and it is reported as nicotine hydrogen tartrate salt (1 mg/kg of nicotine hydrogen tartrate salt equals to $0.35087 \mathrm{mg} / \mathrm{kg}$ nicotine free base). All drugs were administered in a volume of $10 \mathrm{ml} / \mathrm{kg}$.

\subsection{Locomotor activity}

The locomotor responses induced by nicotine hydrogen tartrate salt were evaluated by using small locomotor activity boxes $(9 \times 20 \times 11 \mathrm{~cm})$ (Imetronic, Lyon France) in a low luminosity room (5 lux), and with white noise. Each box contained a line of photocells $2 \mathrm{~cm}$ above the floor to measure horizontal movements, and another line located $6 \mathrm{~cm}$ above the floor to measure vertical activity (rearing). Mice were 
individually placed in the boxes 5 min after nicotine hydrogen tartrate salt or saline injection, respectively, and the number of activity counts was recorded for a period of $10 \mathrm{~min}$.

\subsection{Antinociceptive responses}

Two different nociceptive models where different neural pathways are involved in processing the nociceptive signals, the tail-immersion and the hot-plate test, were used to evaluate the antinociceptive responses induced by nicotine.

Tail-immersion test: The antinociceptive responses were determined as previously reported (Simonin et al. 1998), 15 min after nicotine hydrogen tartrate salt or saline injection. The water temperature was maintained at $50 \pm 0.5^{\circ} \mathrm{C}$ using a thermo regulated water-circulating pump (Clifton, North Somerset UK). The time to withdraw the tail was determined and a cut-off was set-up at $15 \mathrm{~s}$ in order to prevent tissue damage.

Hot-plate test: This test was performed as previously described (Simonin et al. 1998), 16 min after nicotine hydrogen tartrate salt or saline injection. The temperature of the plate (Columbus instruments, Columbus OH USA) was kept at $52 \pm 0.5^{\circ} \mathrm{C}$. The nociceptive threshold evaluated was the jumping response. In absence of jumps, a $240 \mathrm{~s}$ cut-off was used to prevent tissue damage.

Preliminary experiments with subsequent exposure to the tail-immersion and the hotplate test showed that the previous tail-immersion exposure did not influence the results obtained in the hot-plate (Castañé et al. 2002; Matthes et a. 1996) test. Each mouse received only one treatment.

\subsection{Statistical analysis}


The results were analyzed using two-way ANOVA, with NIC (saline or nicotine) and the GABAergic ligand (vehicle or GABAergic ligand) administration as betweensubjects factors of variation, followed by corresponding post-hoc test when appropriate (Tukey's test).

\section{Results}

\subsection{Baclofen did not modify nicotine-induced hypolocomotion}

Nicotine hydrogen tartrate salt ( $3 \mathrm{mg} / \mathrm{kg}, \mathrm{sc})$ similarly decreased vertical and horizontal locomotor activity in animals pre-treated with either baclofen or saline (Fig 1A, B). Two-way ANOVA calculated for vertical locomotor activity revealed a significant effect of nicotine treatment $\left[\mathrm{F}_{(1,73)}=363.456, \mathrm{P}<0.001\right]$, without effect of baclofen pretreatment $\left[\mathrm{F}_{(3,73)}=0.521, \mathrm{NS}\right]$ nor interaction between these two factors $\left[\mathrm{F}_{(3,73)}=0.683\right.$, NS]. Subsequent post-hoc (Tukey) analysis showed a significant effect of nicotine treatment in saline $(\mathrm{P}<0.001)$ and baclofen $(1,2$ and $3 \mathrm{mg} / \mathrm{kg} ; \mathrm{P}<0.001)$ pre-treated mice (Fig. 1A).

Two-way ANOVA calculated for horizontal locomotor activity revealed a significant effect of nicotine treatment $\left[\mathrm{F}_{(1,73)}=394.844, \mathrm{P}<0.001\right]$, without effect of baclofen pretreatment $\left[\mathrm{F}_{(3,73)}=2.439, \mathrm{NS}\right]$ nor interaction between these two factors $\left[\mathrm{F}_{(3,73)}=1.284\right.$, NS]. Subsequent post-hoc (Tukey) analysis showed a significant effect of nicotine treatment in saline $(\mathrm{P}<0.001)$ and baclofen $(1,2$ and $3 \mathrm{mg} / \mathrm{kg} ; \mathrm{P}<0.001)$ pre-treated mice (Fig 1B).

\subsection{Baclofen abolished nicotine-induced antinociception}

Nicotine hydrogen tartrate salt $(3 \mathrm{mg} / \mathrm{kg}, \mathrm{sc})$ induced antinociceptive responses in the tail immersion and the hot plate tests (Fig 2A, B). Baclofen pre-treatment abolished the 
antinociceptive effect of nicotine in both tests (Fig 2A, B). In the tail-immersion test, two-way ANOVA revealed a significant effect of nicotine treatment $\left[\mathrm{F}_{(1,71)}=31.799\right.$, $\mathrm{P}<0.001]$, without effect of baclofen pre-treatment $\left[\mathrm{F}_{(3,71)}=1.933\right.$, NS $]$ and a significant interaction between these two factors $\left[\mathrm{F}_{(1,71)}=8.830, \mathrm{P}<0.001\right]$. Subsequent post-hoc (Tukey) analysis revealed a significant effect of nicotine treatment in the saline $(\mathrm{P}<0.001)$ and baclofen $(1 \mathrm{mg} / \mathrm{kg} ; \mathrm{P}<0.001)$ pre-treated mice, but not in mice pre-treated with 2 and $3 \mathrm{mg} / \mathrm{kg}$ of baclofen. Post-hoc also showed a significant blockade in the antinociceptive response induced by nicotine in the baclofen $(3 \mathrm{mg} / \mathrm{kg} ; \mathrm{P}<0.001)$ pretreated animals, but not in mice pre-treated with 1 and $2 \mathrm{mg} / \mathrm{kg}$ of baclofen (Fig. 2A). In the hot plate, two-way ANOVA revealed a significant effect of nicotine treatment $\left[\mathrm{F}_{(1,72)}=144.662, \mathrm{P}<0.001\right]$, baclofen pre-treatment $\left[\mathrm{F}_{(3,72)}=14.174, \mathrm{P}<0.001\right]$ and interaction between these two factors $\left[\mathrm{F}_{(1,72)}=16.491, \mathrm{P}<0.001\right]$. Subsequent post-hoc (Tukey) analysis revealed a significant effect of nicotine treatment in the saline $(\mathrm{P}<0.001)$ and baclofen $(1$ and $2 \mathrm{mg} / \mathrm{kg} ; \mathrm{P}<0.001)$ pre-treated mice, but not in mice pretreated with $3 \mathrm{mg} / \mathrm{kg}$ of baclofen. Post-hoc also showed a significant blockade of nicotine antinociceptive responses in the baclofen $(3 \mathrm{mg} / \mathrm{kg} ; \mathrm{P}<0.001)$ pre-treated animals, but not in mice pre-treated with 1 and $2 \mathrm{mg} / \mathrm{kg}$ of baclofen (Fig. 2B).

\subsection{2-hydroxysaclofen abolished nicotine-induced hypolocomotion}

Nicotine hydrogen tartrate salt ( $3 \mathrm{mg} / \mathrm{kg}, \mathrm{sc}$ ) similarly decreased vertical and horizontal locomotor activity in animals pre-treated with glucose 5\% (Fig 3A, B). 2hydroxysaclofen pre-treatment abolished nicotine hypolocomotor effects (Fig 3A, B). Two-way ANOVA calculated for vertical locomotor activity revealed a significant effect of nicotine treatment $\left[\mathrm{F}_{(1,56)}=35.309, \mathrm{P}<0.001\right]$, 2-hydroxysaclofen pre-treatment $\left[\mathrm{F}_{(3,56)}=6.353, \mathrm{P}<0.001\right]$ and a significant interaction between these two factors 
$\left[\mathrm{F}_{(3,56)}=4.544, \mathrm{P}<0.01\right]$. Subsequent post - hoc (Tukey) analysis showed a significant effect of nicotine treatment in glucose 5\% $(\mathrm{P}<0.001)$ and 2-hydroxysaclofen $(0.25$ $\mathrm{mg} / \mathrm{kg} ; \mathrm{P}<0.01)$ pre-treated mice, but not in mice pre-treated with 0.5 and $1 \mathrm{mg} / \mathrm{kg}$ of 2hydroxysaclofen. Post-hoc also showed a significant blockade of nicotine hypolocomotor responses in the 2-hydroxysaclofen $(1 \mathrm{mg} / \mathrm{kg} ; \mathrm{P}<0.001)$ pre-treated animals, but not in mice pre-treated with 0.25 and $0.5 \mathrm{mg} / \mathrm{kg}$ of 2-hydroxysaclofen (Fig. $3 \mathrm{~A})$.

Two-way ANOVA calculated for horizontal locomotor activity revealed a significant effect of nicotine treatment $\left[\mathrm{F}_{(1,56)}=12.460, \mathrm{P}<0.001\right]$, 2-hydroxysaclofen pre-treatment $\left[\mathrm{F}_{(3,56)}=2.942, \mathrm{P}<0.05\right]$ and a significant interaction between these two factors $\left[\mathrm{F}_{(3,56)}=3.215, \mathrm{P}<0.05\right]$. Subsequent post-hoc $($ Tukey) analysis showed a significant effect of nicotine treatment in glucose $5 \%(\mathrm{P}<0.01)$ pre-treated mice, but not in mice pre-treated with $0.25,0.5$ and $1 \mathrm{mg} / \mathrm{kg}$ of 2-hydroxysaclofen. Post-hoc also showed a significant blockade of nicotine hypolocomotor responses in the 2-hydroxysaclofen (1 $\mathrm{mg} / \mathrm{kg} ; \mathrm{P}<0.01$ ) pre-treated animals, but not in mice pre-treated with 0.25 and $0.5 \mathrm{mg} / \mathrm{kg}$ of 2-hydroxysaclofen (Fig. 3B).

\subsection{2-hydroxysaclofen increased nicotine-induced antinociception}

Nicotine hydrogen tartrate salt $(3 \mathrm{mg} / \mathrm{kg}, \mathrm{sc})$ induced antinociceptive responses in the tail immersion and the hot plate tests (Fig 4A, B). 2-hydroxysaclofen pre-treatment increased the antinociceptive effects of nicotine in both tests (Fig 4A, B). In the tailimmersion test, two-way ANOVA revealed a significant effect of nicotine treatment $\left[\mathrm{F}_{(1,56)}=268.720, \mathrm{P}<0.001\right], 2$-hydroxysaclofen pre-treatment $\left[\mathrm{F}_{(3,56)}=16.471, \mathrm{P}<0.001\right]$ and a significant interaction between these two factors $\left[\mathrm{F}_{(3,56)}=13.886, \mathrm{P}<0.001\right]$. Subsequent post-hoc (Tukey) analysis revealed a significant effect of nicotine treatment 
in the glucose $5 \%(\mathrm{P}<0.05)$ and 2-hydroxysaclofen $(0.25,0.5$ and $1 \mathrm{mg} / \mathrm{kg} ; \mathrm{P}<0.001)$ pre-treated mice. Post-hoc also showed a significant increase in the antinociceptive response induced by nicotine in the 2-hydroxysaclofen $(0.25,0.5$ and $1 \mathrm{mg} / \mathrm{kg} ; \mathrm{P}<0.05$, $\mathrm{P}<0.001, \mathrm{P}<0.001$; respectively) pre-treated animals (Fig. 4A).

In the hot plate, two-way ANOVA revealed a significant effect of nicotine treatment $\left[\mathrm{F}_{(1,56)}=701.993, \mathrm{P}<0.001\right], 2$-hydroxysaclofen pre-treatment $\left[\mathrm{F}_{(3,56)}=9.320, \mathrm{P}<0.001\right]$ and interaction between these two factors $\left[\mathrm{F}_{(1,56)}=8.583, \mathrm{P}<0.001\right]$. Subsequent post-hoc (Tukey) analysis revealed a significant effect of nicotine treatment in the glucose 5\% $(\mathrm{P}<0.001)$ and 2-hydroxysaclofen $(0.25,0.5$ and $1 \mathrm{mg} / \mathrm{kg} ; \mathrm{P}<0.001)$ pre-treated mice. Post-hoc also showed a significant increase of nicotine antinociceptive responses in the 2-hydroxysaclofen $(1 \mathrm{mg} / \mathrm{kg} ; \mathrm{P}<0.001)$ pre-treated animals, but not in mice pre-treated with 0.25 and $0.5 \mathrm{mg} / \mathrm{kg}$ of 2-hydroxysaclofen (Fig. 4B).

\section{Discussion}

Our results demonstrate that acute administration of the $\mathrm{GABA}_{\mathrm{B}}$ agonist baclofen did not modify nicotine-induced hypolocomotion, but abolished nicotine antinociceptive responses. In addition, the $\mathrm{GABA}_{\mathrm{B}}$ antagonist 2-hydroxysaclofen abolished nicotineinduced hypolocomotion and increased the antinociception induced by nicotine. The hypolocomotor effect induced by nicotine $(3 \mathrm{mg} / \mathrm{kg})$ is in accordance with previous studies from our groups (Berrendero et al. 2005; Castañe et al. 2002; Varani et al. 2012). Baclofen (1, 2 and $3 \mathrm{mg} / \mathrm{kg}$; ip) did not modify locomotor activity nor nicotineinduced hypolocomotion under our experimental conditions. The results confirm that these doses of baclofen alone do not have specific locomotor effects, as previously reported (Frankowska et al. 2007; Holstein and Phillips 2006; Varani and Balerio 2012). We also previously observed that baclofen $(2 \mathrm{mg} / \mathrm{kg}$, ip) does not induce motor 
incoordination or sedation in saline treated mice in the rota-rod test (Balerio and Rubio 2002). In the present study, the fact that baclofen did not modify nicotine-induced hypolocomotor effects might be attributed to a possible maximum effect reached by the endogenous GABAergic system in its participation on this nicotine behavioral response. On the other hand, the antagonist 2-hydroxysaclofen given at different doses $(0.25,0.5$ and $1 \mathrm{mg} / \mathrm{kg}$ ) did not modify the locomotor activity, in agreement with previous studies (Abraini et al. 2003; Kalivas et al. 2001; Varani and Balerio 2012). Our findings show that $\mathrm{GABA}_{\mathrm{B}}$ receptor activity is required for nicotine hypolocomor effect since this response was abolished by 2-hydroxysaclofen pre-treatment $(1 \mathrm{mg} / \mathrm{kg})$. In agreement, we recently found that nicotine-induced hypolocomotion was attenuated in $\mathrm{GABA}_{\mathrm{B} 1}$ knockout mice (Varani et al. 2012), suggesting a role for $\mathrm{GABA}_{\mathrm{B}}$ receptors in this response. All together, these findings suggest that the lack of a $\mathrm{GABA}_{\mathrm{B}}$ receptor tone, but not its activation by baclofen modifies nicotine hypolocomotor effects.

Nicotine antinociceptive responses were evaluated in the tail-immersion and hot-plate tests, two models with different neuronal pathways involved in the processing of nociceptive signals. The tail-immersion mainly evokes a response mediated by a spinal reflex (Caggiula et al. 1995), whereas responses to the hot-plate require supraspinal integration of the nociceptive stimuli (Caggiula et al. 1995; Rubinstein et al. 1996). Nicotine $(3 \mathrm{mg} / \mathrm{kg})$ induced antinociceptive effects in both tests, as previously reported (Galeote et al. 2008; Trigo et al. 2009; Varani et al. 2012). Baclofen alone did not modify nociceptive responses in the tail-immersion and the hot-plate test, in agreement with previous studies (Blednov et al. 2003), although contradictory results have been previously reported in the hot-plate test (Balerio and Rubio 2002). This discrepancy could be explained by the use of a different hot-plate temperature (Imamachi et al. 2009) in these previous studies. In the present study, baclofen $(3 \mathrm{mg} / \mathrm{kg})$ pre-treatment 
abolished nicotine-induced antinociception in the tail-immersion and hot-plate test. Several authors have reported interactions between baclofen and nicotine in other behavioral responses. Thus, baclofen reduces both nicotine self-administration (Corrigall et al. 2000; Fattore et al. 2002; Paterson et al. 2004) and conditioned place preference (Le Foll et al. 2008) in rats. In addition, we have shown that baclofen prevents nicotine rewarding properties and negative aspects of nicotine withdrawal, such as anxiety-like effects and somatic manifestations (Varani et al. 2011, 2014). All these findings together support the acute interactions between baclofen and nicotine behavioral responses related to its addictive properties. Nicotine antinociception is mediated, at least in part, by serotonin release in the spinal cord from the nucleus raphe magnus neurons (Bannon et al. 1998; Iwamoto 1991). Therefore, the activation by baclofen of $\mathrm{GABA}_{\mathrm{B}}$ receptors located in serotonergic neurons of the raphe magnus nucleus could induce a decrease of serotonin release in the spinal cord, leading to the subsequent prevention of nicotine antinociceptive effects. On the other hand, 2hydroxysaclofen $(1 \mathrm{mg} / \mathrm{kg})$ pre-treatment increased nicotine antinociception in the tailimmersion and the hot-plate test. These findings also imply an interaction between $\mathrm{GABA}_{\mathrm{B}}$ and cholinergic nicotinic systems in the control of nociceptive responses. We suggest that 2-hydroxysaclofen might block $\mathrm{GABA}_{\mathrm{B}}$ receptors located in serotonergic neurons of the raphe magnus nucleus producing the opposite effect to baclofen on nicotine antinociception. Interestingly, we recently found that nicotine-induced antinociception in the tail-immersion and hot-plate tests was abolished in $\mathrm{GABA}_{\mathrm{B} 1}$ knockout mice (Varani et al. 2012), which might reflect a compensatory regulation of other neurobiological mechanisms involved in nicotine antinociception. In this sense, it is well known that the endogenous opioid and cannabinoid systems have been involved in the nicotine-induced antinociception (Berrendero et al. 2002, 2005, 2010; Castañé et 
al. 2002; Galeote et al. 2006, 2008; Valjent et al. 2002). Possible changes on these systems might exert a compensatory mechanism to compensate the lack of $\mathrm{GABA}_{\mathrm{B}}$ receptors in the $\mathrm{GABA}_{\mathrm{B} 1}$ knockout mice.

5. Conclusion: we provide the first pharmacological evidence of the specific involvement of $\mathrm{GABA}_{\mathrm{B}}$ receptors in the regulation of the hypolocomotion and antinociception induced by nicotine in mice. An interaction between the $\mathrm{GABA}_{B}$ receptors and the cholinergic systems on these behavioral responses has been now revealed using both baclofen and 2-hydroxysaclofen. The elucidation of this interaction provides a further step towards a better understanding of the nicotine behavioral responses. Finally, these data underline the interest of $\mathrm{GABA}_{\mathrm{B}}$ receptor as a potential target for the development of novel therapeutics approaches for nicotine addiction (Franklin et al. 2009; Markou et al. 2004). 


\section{Acknowledgements}

This work has been supported by grants from University of Buenos Aires (UBACyT B016 and UBACyT 2013-2016 Nº 20020120100244), CONICET (PIP 11420090100303), Spanish "Ministerio de Ciencia e Innovación" (\#SAF2011-29864), "Instituto de Salud Carlos III" (RETICS: \#RD06/0001/0001, \#RD06/0001/1004), Plan Nacional sobre Drogas (PNSD \#2009/026), the Catalan Government (SGR2009-00131) and the ICREA Foundation (ICREA Academia-2008). Andrés P. Varani is a doctoral fellow of the University of Buenos Aires (6936/2013). The organizations have no further role in study design; in the collection, analysis and interpretation of the data; in the writing of the report; or in the decision to submit the paper for publication. The experiments comply with the current laws of the country in which they were performed. The authors declare they have no a financial relationship with the organizations that supported the research.

\section{Conflicts of interest}

All authors declare they have no conflicts of interest. 


\section{References}

Abraini, J.H., Kriem, B., Balon, N., Rostain, J.C., Risso, J.J., 2003. Gammaaminobutyric acid neuropharmacological investigations on narcosis produced by nitrogen, argon, or nitrous oxide. Anesth. Analg. 96(3), 746-9.

Balerio, G.N., Rubio, M.C., 2002. Baclofen analgesia: involvement of the GABAergic system. Pharmacol. Res. 46(3), 281-86.

Bannon, A.W., Decker, M.W., Holladay, M.W., Curzon, P., Donnelly-Roberts, D., Puttfarcken, P.S., Bitner, R.S., Diaz, A., Dickenson, A.H., Porsolt, R.D., Williams, M., Arneric, S.P., 1998. Broad-spectrum, non-opioid analgesic activity by selective modulation of neuronal nicotinic acetylcholine receptors. Science. 279, 77-81.

Barnard, E.A., Skolnick, P., Olsen, R.W., Mohler, H., Sieghart, W., Biggio, G., Braestrup, C., Bateson, A.N., Langer, S.Z., 1998. International Union of Pharmacology. XV. Subtypes of gamma-aminobutyric acidA receptors: classification on the basis of subunit structure and receptor function. Pharmacol. Rev. 50, 291-313.

Berrendero, F., Kieffer, B.L., Maldonado, R., 2002. Attenuation of nicotine-induced antinociception, rewarding effects, and dependence in mu-opioid receptor knock-out mice. J. Neurosci. 22(24), 10935-40.

Berrendero, F., Mendizábal, V., Robledo, P., Galeote, L., Bilkei-Gorzo, A., Zimmer, A., Maldonado, R., 2005. Nicotine-induced antinociception, rewarding effects, and physical 
dependence are decreased in mice lacking the preproenkephalin gene. J. Neurosci. 25(5), 1103-12.

Berrendero, F., Robledo, P., Trigo, J.M., Martín-García, E., Maldonado, R., 2010. Neurobiological mechanisms involved in nicotine dependence and reward: participation of the endogenous opioid system. Neurosci. Biobehav. Rev. 35(2), 220-31.

Blednov, Y.A., Stoffel, M., Alva, H., Harris, R.A., 2003. A pervasive mechanism for analgesia: activation of GIRK2 channels. Proc. Natl. Acad. Sci. USA. 100(1), 277-82.

Bowery, N.G., Bettler, B., Froestl, W., Gallagher, J.P., Marshall, F., Raiteri, M., Bonner, T.I., Enna, S.J. 2002. International Union of Pharmacology. XXXIII. Mammalian gamma-aminobutyric acid(B) receptors: structure and function. Pharmacol. Rev. 54, 247-64.

Caggiula, A.R., Epstein, L.H., Perkins, K.A., Saylor, S., 1995. Different methods of assessing nicotine-induced antinociception may engage different neuronal mechanisms. Psychopharmacology. 122, 301-6.

Castañé, A., Valjent, E., Ledent, C., Parmentier, M., Maldonado, R., Valverde, O., 2002. Lack of CB1 cannabinoid receptors modifies nicotine behavioural responses, but not nicotine abstinence. Neuropharmacology. 43, 857-67. 
Corrigall, W.A., Coen, K.M., Adamson, K.L., Chow, J.Z., 2000. Response of nicotine self-administration in the rat to manipulations of mu-opioid and $\gamma$-aminobutyric acid receptors in the ventral tegmental area. Psychopharmacology (Berl). 149, 107-14.

Cousins, M.S., Roberts, D.C., de Wit, H., 2002. GABA $(\mathrm{B})$ receptor agonists for the treatment of drug addiction: a review of recent findings. Drug. Alcohol. Depend. 65(3), 209-20.

Dani, J.A., Balfour, D.J., 2011. Historical and current perspective on tobacco use and nicotine addiction. Trends Neurosci. 34(7), 383-92.

Fattore, L., Cossu, G., Martellotta, M.C., Fratta, W., 2002. Baclofen antagonizes intravenous self-administration of nicotine in mice and rats. Alcohol Alcohol. 37(5), 495-8.

Fattore, L., Spano, M.S., Cossu, G., Scherma, M., Fratta, W., Fadda, P., 2009. Baclofen prevents drug-induced reinstatement of extinguished nicotine-seeking behaviour and nicotine place preference in rodents. Eur. Neuropsychopharmacol. 19, 487-98.

Franklin, T.R., Harper, D., Kampman, K., Kildea-McCrea, S., Jens, W., Lynch, K.G.,

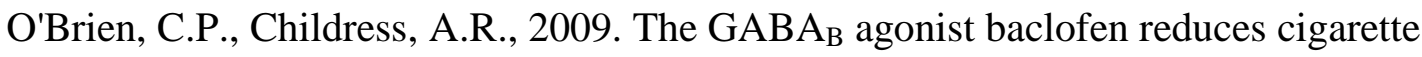
consumption in a preliminary double-blind placebo-controlled smoking reduction study. Drug Alcohol Depend. 103(1-2), 30-6. 
Frankowska, M., Filip, M., Przegaliński, E., 2007. Effects of GABA B receptor ligands in animal tests of depression and anxiety. Pharmacol. Rep. 59(6), 645-55.

Galeote, L., Kieffer, B.L., Maldonado, R., Berrendero, F., 2006. Mu-opioid receptors are involved in the tolerance to nicotine antinociception. J. Neurochem. 97(2), 416-23.

Galeote, L., Maldonado, R., Berrendero, F., 2008. Involvement of kappa/dynorphin system in the development of tolerance to nicotine-induced antinociception. J. Neurochem. 105, 1358-68.

Holstein, S.E., Phillips, T.J., 2006. GABA B receptor stimulation accentuates the locomotor effects of morphine in mice bred for extreme sensitivity to the stimulant effects of ethanol. Pharmacol. Biochem. Behav. 85(4), 697-704.

Imamachi, N., Park, G.H., Lee, H., Anderson, D.J., 2009. Simon MI, Basbaum AI, Han SK. TRPV1-expressing primary afferents generate behavioral responses to pruritogens via multiple mechanisms. Proc. Natl. Acad. Sci. USA. 106, 11330-5.

Iwamoto, E.T., 1991. Characterization of the antinociception induced by nicotine in the pedunculopontine tegmental nucleus and the nucleus raphe magnus. J. Pharmacol. Exp. Ther. 257, 120-33.

Kalivas, P.W., Jackson, D., Romanidies, A., Wyndham, L., Duffy, P., 2001. Involvement of pallidothalamic circuitry in working memory. Neuroscience. 104(1), 129-36. 
Le Foll, B., Wertheim, C.E., Goldberg, S.R., 2008. Effects of baclofen on conditioned rewarding and discriminative stimulus effects of nicotine in rats. Neurosci. Lett. 443(3), $236-40$.

Markou, A., Paterson, N.E., Semenova, S., 2004. Role of gamma-aminobutyric acid (GABA) and metabotropic glutamate receptors in nicotine reinforcement: potential pharmacotherapies for smoking cessation. Ann. N. Y. Acad. Sci. 1025, 491-503.

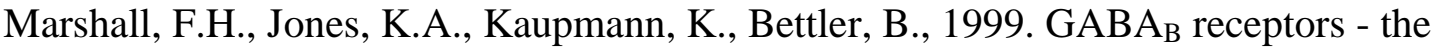
first 7TM heterodimers. Trends Pharmacol. Sci. 20, 396-99.

Matthes, H.W., Maldonado, R., Simonin, F., Valverde, O., Slowe, S., Kitchen, I., Befort, K., Dierich, A., Le Meur, M., Dollé, P., Tzavara, E., Hanoune, J., Roques, B.P., Kieffer, B.L., 1996. Loss of morphine-induced analgesia, reward effect and withdrawal symptoms in mice lacking the mu-opioid-receptor gene. Nature. 383(6603), 819-23.

Millar, N.S., Gotti, C., 2009. Diversity of vertebrate nicotinic acetylcholine receptors. Neuropharmacology. 56, 237-46.

Paterson, N.E., Froestl, W., Markou, A., 2004. The GABA B $_{\text {receptor agonists baclofen }}$ and CGP44532 decreased nicotine self-administration in the rat. Psychopharmacology (Berl). 172(2), 179-86. 
Paterson, N.E., 2009. The neuropharmacological substrates of nicotine reward: reinforcing versus reinforcement-enhancing effects of nicotine. Behav. Pharmacol. 20(3), 211-25.

Picciotto, M.R., Corrigall, W.A., 2002. Neuronal systems underlying behaviors related to nicotine addiction: neural circuits and molecular genetics. J. Neurosci. 22, 3338-41.

Rubinstein, M., Mogil, J.S., Japơn, M., Chan, E.C., Allen, R.G., Low, M.J., 1996. Absence of opioid stress-induced analgesia in mice lacking beta-endorphin by sitedirected mutagenesis. Proc. Natl. Acad. Sci. USA. 93, 3995-4000.

SENASA (Resolución 617/2002): Requisitos, condiciones y procedimientos para la habilitación técnica de laboratorios que posean bioterios de producción, mantenimiento y local de experimentación.

Simonin, F., Valverde, O., Smadja, C., Slowe, S., Kitchen, I., Dierich, A., Le Meur, M., Roques, B.P., Maldonado, R., Kieffer, B.L., 1998. Disruption of the kappa-opioid receptor gene in mice enhances sensitivity to chemical visceral pain, impairs pharmacological actions of the selective kappa-agonist U-50,488H and attenuates morphine withdrawal. EMBO. J. 17, 886-97.

Trigo, J.M., Zimmer, A., Maldonado, R., 2009. Nicotine anxiogenic and rewarding effects are decreased in mice lacking beta-endorphin. Neuropharmacology. 56, 1147-53. 
Valjent, E., Mitchell, J.M., Besson, M.J., Caboche, J., Maldonado, R., 2002.

Behavioural and biochemical evidence for interactions between Delta 9-

tetrahydrocannabinol and nicotine. Br. J. Pharmacol. 135(2), 564-78.

Varani, A.P., Aso, E., Moutinho Machado, L., Maldonado, R., Balerio, G.N., 2014. Attenuation by baclofen of nicotine rewarding properties and nicotine withdrawal manifestations. Psychopharmacology (Berl). doi:10.1007/s00213-014-3469-6.

Varani, A.P., Balerio, G.N., 2012. GABA B $_{\mathrm{B}}$ receptors involvement in the effects induced by nicotine on anxiety-related behaviour in mice. Pharmacol. Res. 65, 507-13.

Varani, A.P., Moutinho Machado, L., Bettler, B., Balerio, G.N., 2012. Acute behavioural responses to nicotine and nicotine withdrawal syndrome are modified in $\mathrm{GABA}_{(\mathrm{B} 1)}$ knockout mice. Neuropharmacology. 63, 863-72.

Varani, A.P., Moutinho Machado, L., Calvo, M., Balerio, G.N., 2011. Ability of baclofen to prevent somatic manifestations and neurochemical changes during nicotine withdrawal. Drug Alcohol Depend. 119, 5-12. 


\section{Figures Legends}

Fig 1. Baclofen (BAC) did not modify the hypolocomotion induced by nicotine.

Vertical (A) and horizontal (B) activity were measured 50 and 5 min after BAC (1, 2 and $3 \mathrm{mg} / \mathrm{kg}$; i.p) or vehicle (saline, VEH) and nicotine hydrogen tartrate salt (NIC; 3 $\mathrm{mg} / \mathrm{kg}$; s.c.) or saline (SAL) injection, respectively. Results are expressed as mean \pm S.E.M. ( $\mathrm{n}=10-11$ mice for each group) of photocell counts during a 10-min period in mice. Statistical analysis was performed using two-way ANOVA with chronic treatment (SAL or NIC) and acute treatment (VEH or BAC) as between-subjects factors of variation, followed by Fisher's post-hoc test. $\star \star \star P<0.001$ when compared to VEHSAL group.

Fig. 2. Baclofen (BAC) (3 mg/kg, ip) abolished the antinociceptive responses induced by nicotine. Antinociceptive responses in the tail-immersion (A) and hot-plate (B) tests were measured 15 and $16 \mathrm{~min}$ after nicotine hydrogen tartrate salt (NIC; $3 \mathrm{mg} / \mathrm{kg}$; s.c.) or saline (SAL) injection, respectively. BAC (1, 2 and $3 \mathrm{mg} / \mathrm{kg}$; i.p) or vehicle (saline, $\mathrm{VEH})$ were injected $45 \mathrm{~min}$ before NIC or SAL injection. Results are expressed as mean \pm S.E.M. ( $\mathrm{n}=8-11$ mice for each group) of latency time (in seconds) in mice. Statistical analysis was performed using two-way ANOVA with chronic treatment (SAL or NIC) and acute treatment (VEH or BAC) as between-subjects factors of variation, followed

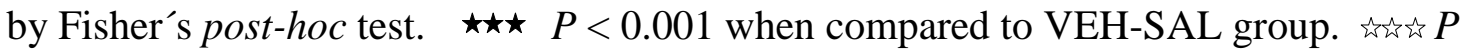
$<0.001$ when compared to VEH-NIC group. 
Fig. 3. 2-hydroxysaclofen (SAC) (1 mg/kg, ip) abolished the hypolocomotion induced by nicotine. Vertical (A) and horizontal (B) activity were measured 15 and 5 min after SAC $(0.25,0.5$ and $1 \mathrm{mg} / \mathrm{kg}$; i.p) or vehicle (glucose 5\%, VEH) and nicotine hydrogen tartrate salt (NIC; $3 \mathrm{mg} / \mathrm{kg}$; s.c.) or saline (SAL) injection, respectively. Results are expressed as mean \pm S.E.M. ( $\mathrm{n}=10$-11 mice for each group) of photocell counts during a 10-min period in mice. Statistical analysis was performed using two-way ANOVA with chronic treatment (SAL or NIC) and acute treatment (VEH or SAC) as betweensubjects factors of variation, followed by Fisher's post-hoc test. $\star \star P<0.01 ; \star \star \star P<$

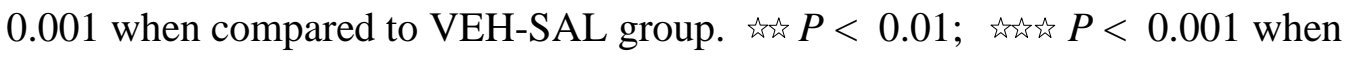
compared to VEH-NIC group.

Fig 4. 2-hydroxysaclofen $(\mathrm{SAC})(1 \mathrm{mg} / \mathrm{kg}$, ip) increased the antinociceptive responses induced by nicotine. Antinociceptive responses in the tail-immersion (A) and hot-plate (B) tests were measured 15 and 16 min after nicotine hydrogen tartrate salt (NIC; 3 $\mathrm{mg} / \mathrm{kg}$; s.c.) or saline (SAL) injection, respectively. SAC $(0.25,0.5$ and $1 \mathrm{mg} / \mathrm{kg}$; i.p) or vehicle (glucose 5\%, VEH) were injected 10 min before NIC or SAL injection. Results are expressed as mean \pm S.E.M. $(n=8$-11 mice for each group) of latency time (in seconds) in mice. Statistical analysis was performed using two-way ANOVA with chronic treatment (SAL or NIC) and acute treatment (VEH or SAC) as between-subjects factors of variation, followed by Fisher's post-hoc test. $\star P<0.05 ; \star \star \star P<0.001$ when compared to VEH-SAL group. is $P<0.05$; 站败 $P<0.001$ when compared to VEH-NIC group. 
A Vertical locomotor activity

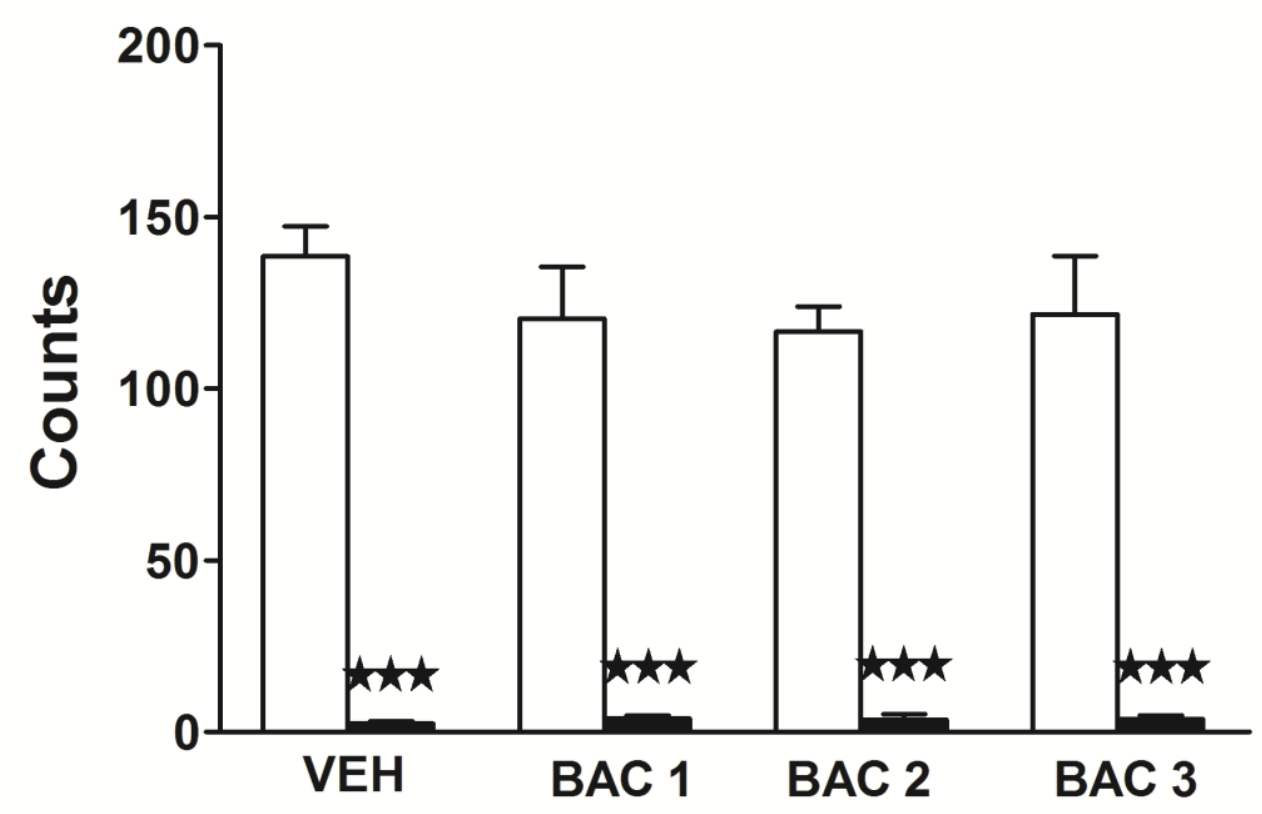

B Horizontal locomotor activity

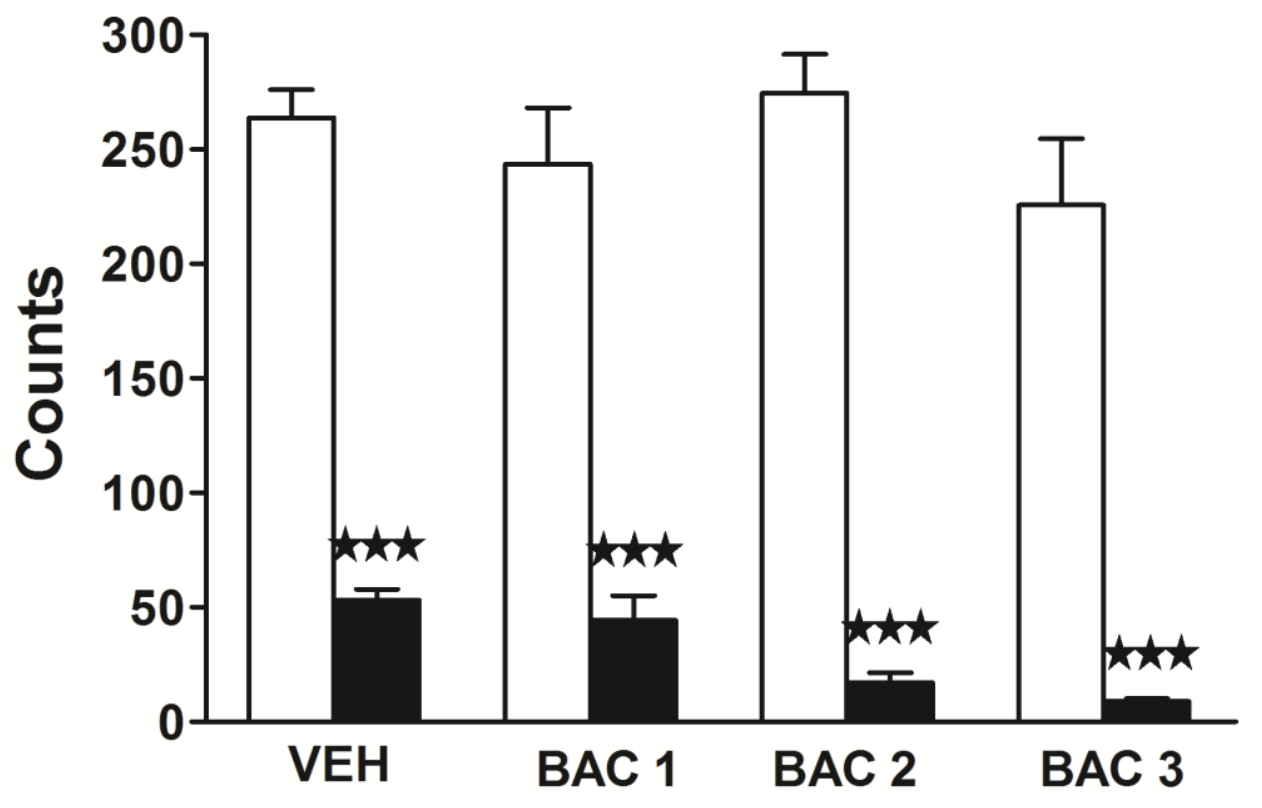

\section{$\square$ SAL \\ NIC}


A Tail-immersion

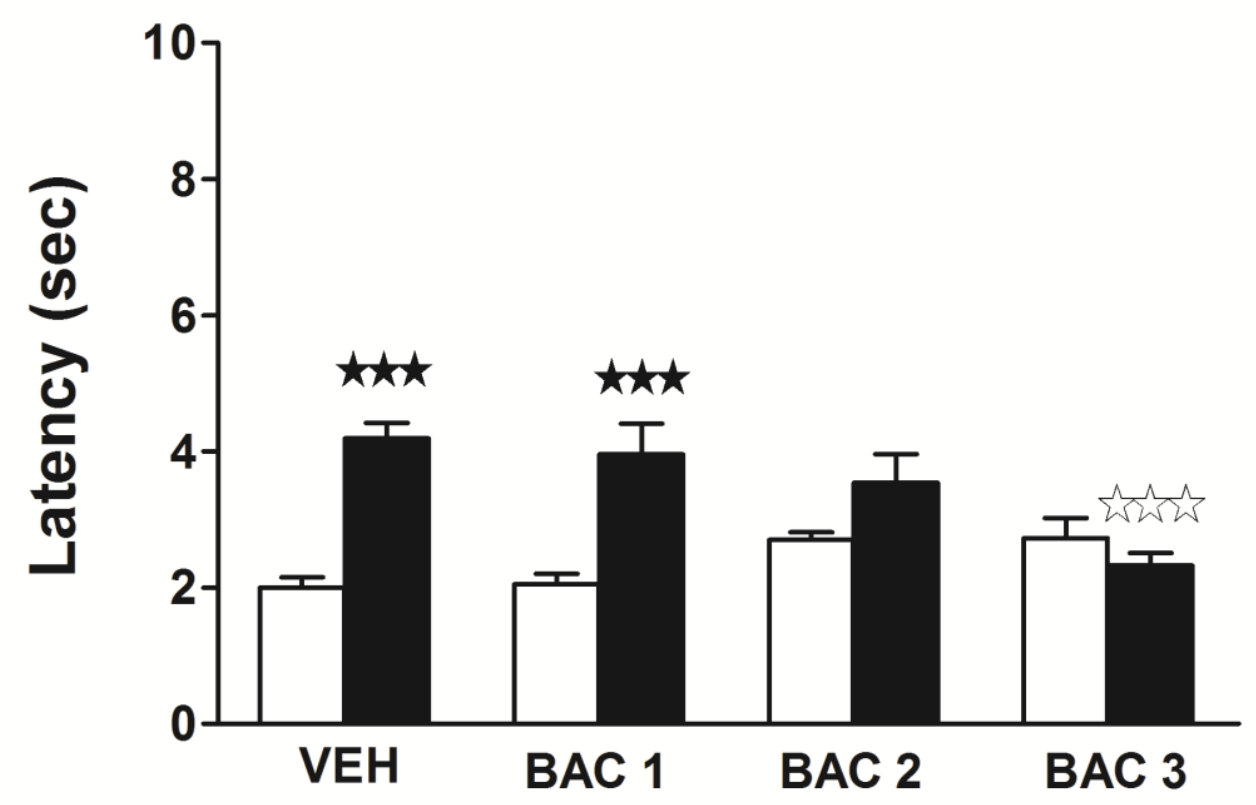

B Hot-plate

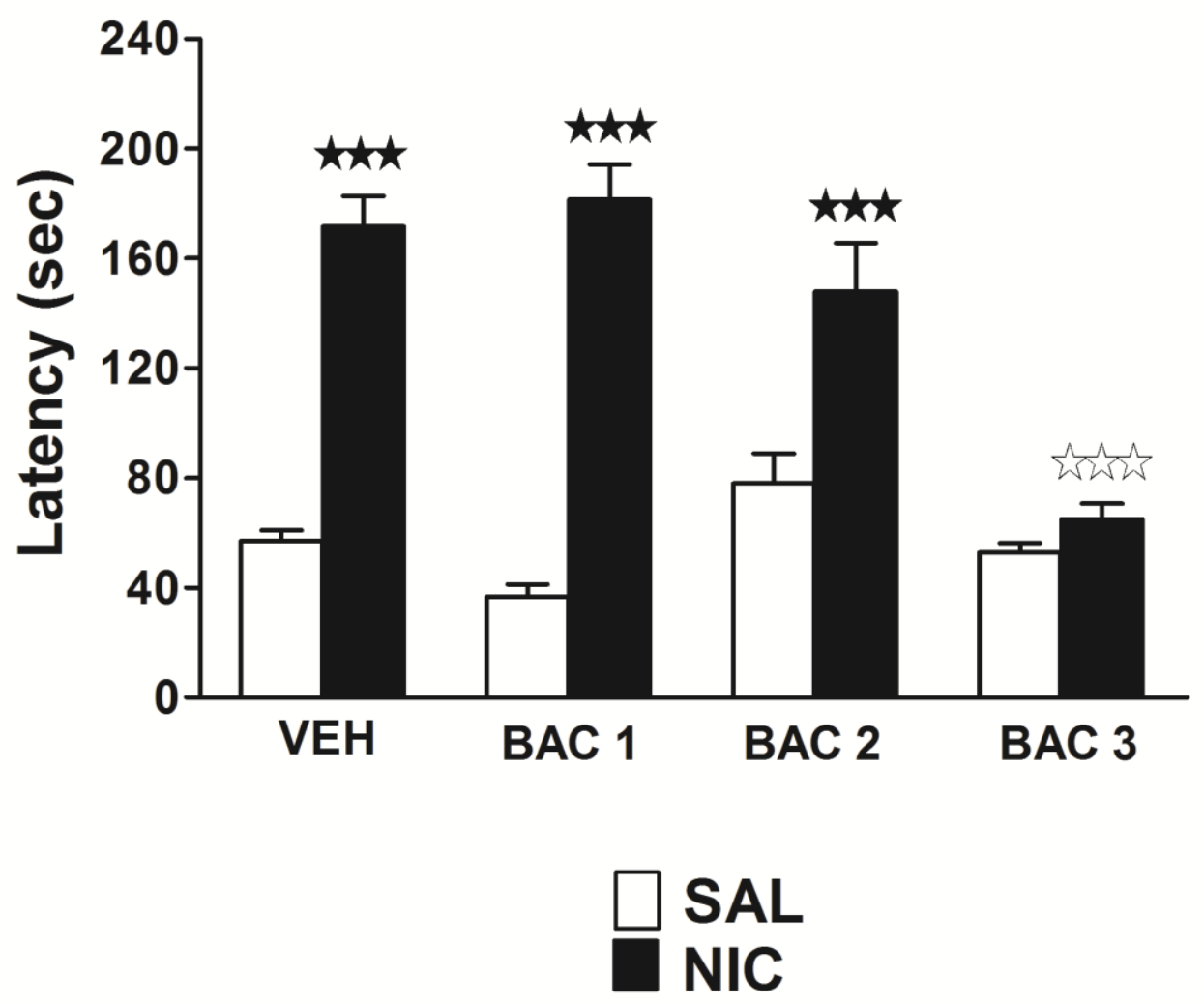


A Vertical locomotor activity

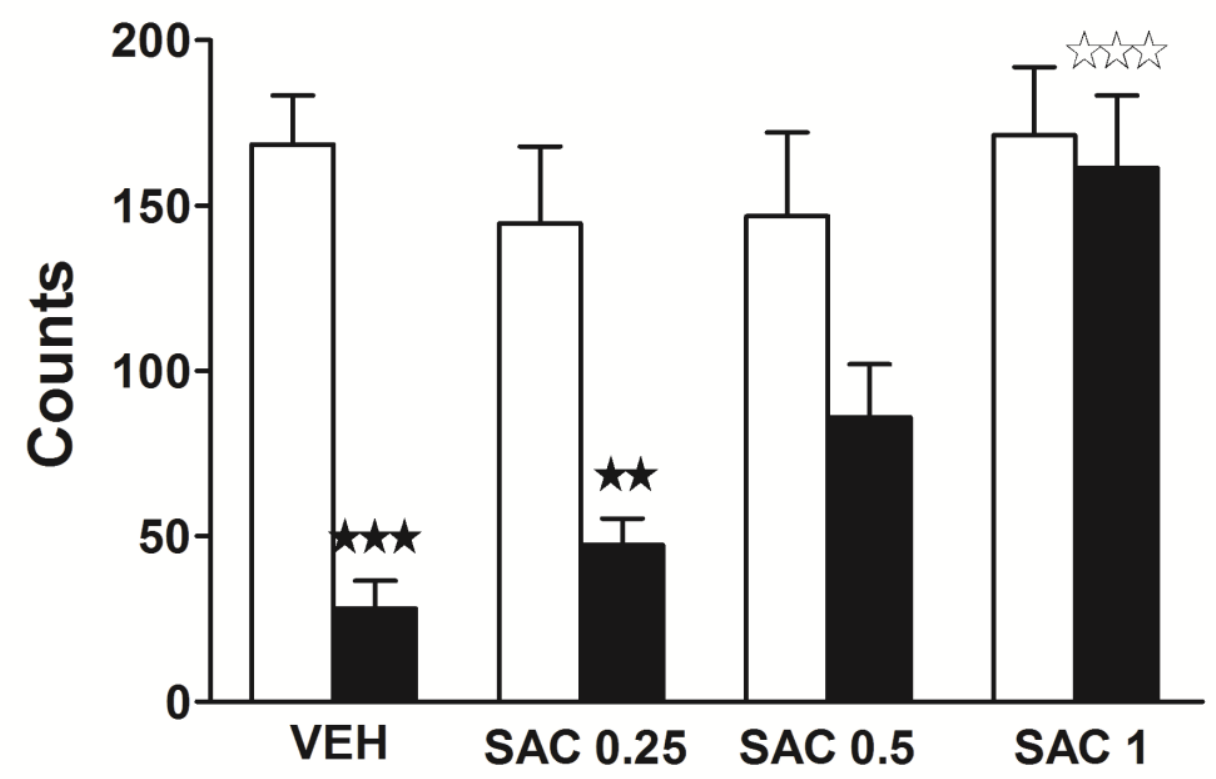

B Horizontal locomotor activity

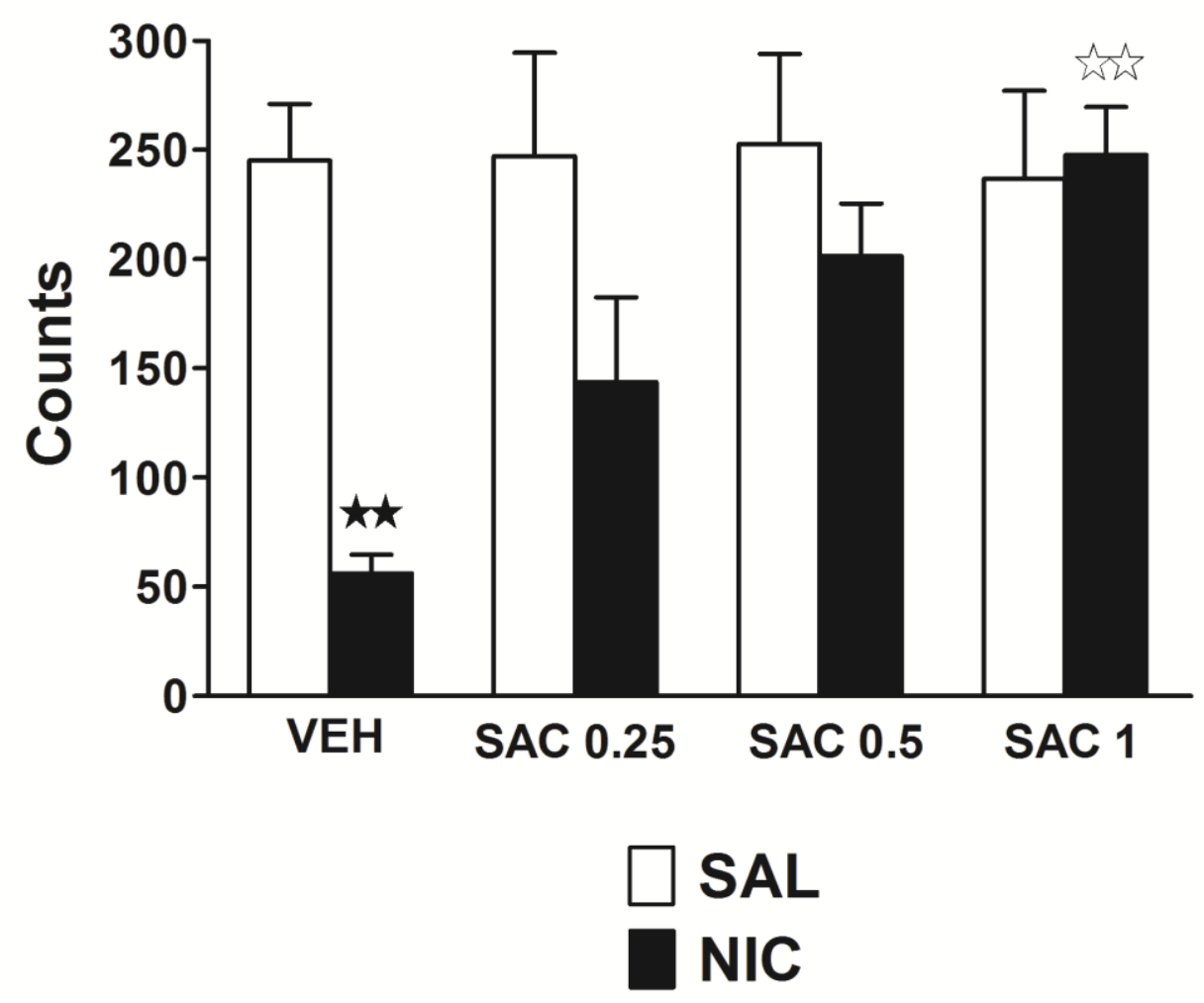


A

Tail-immersion

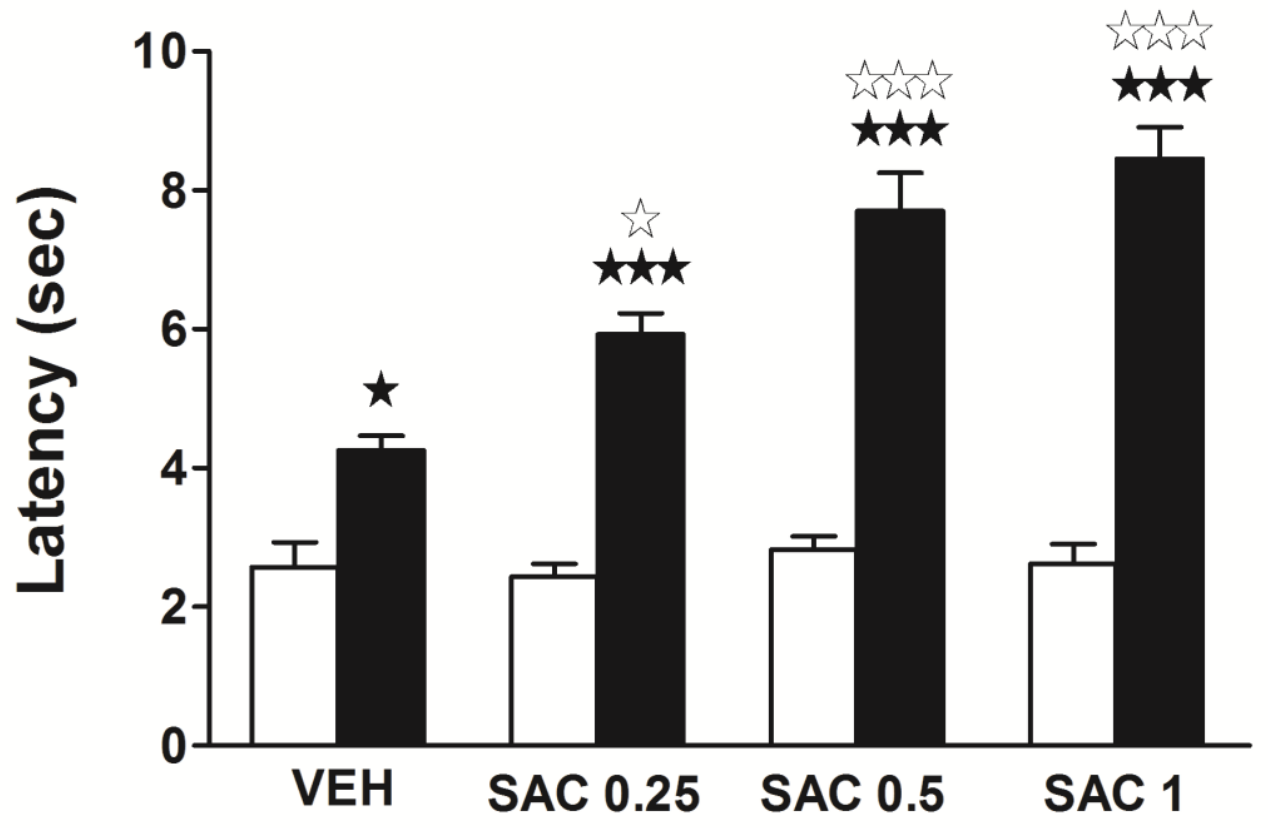

B Hot-plate

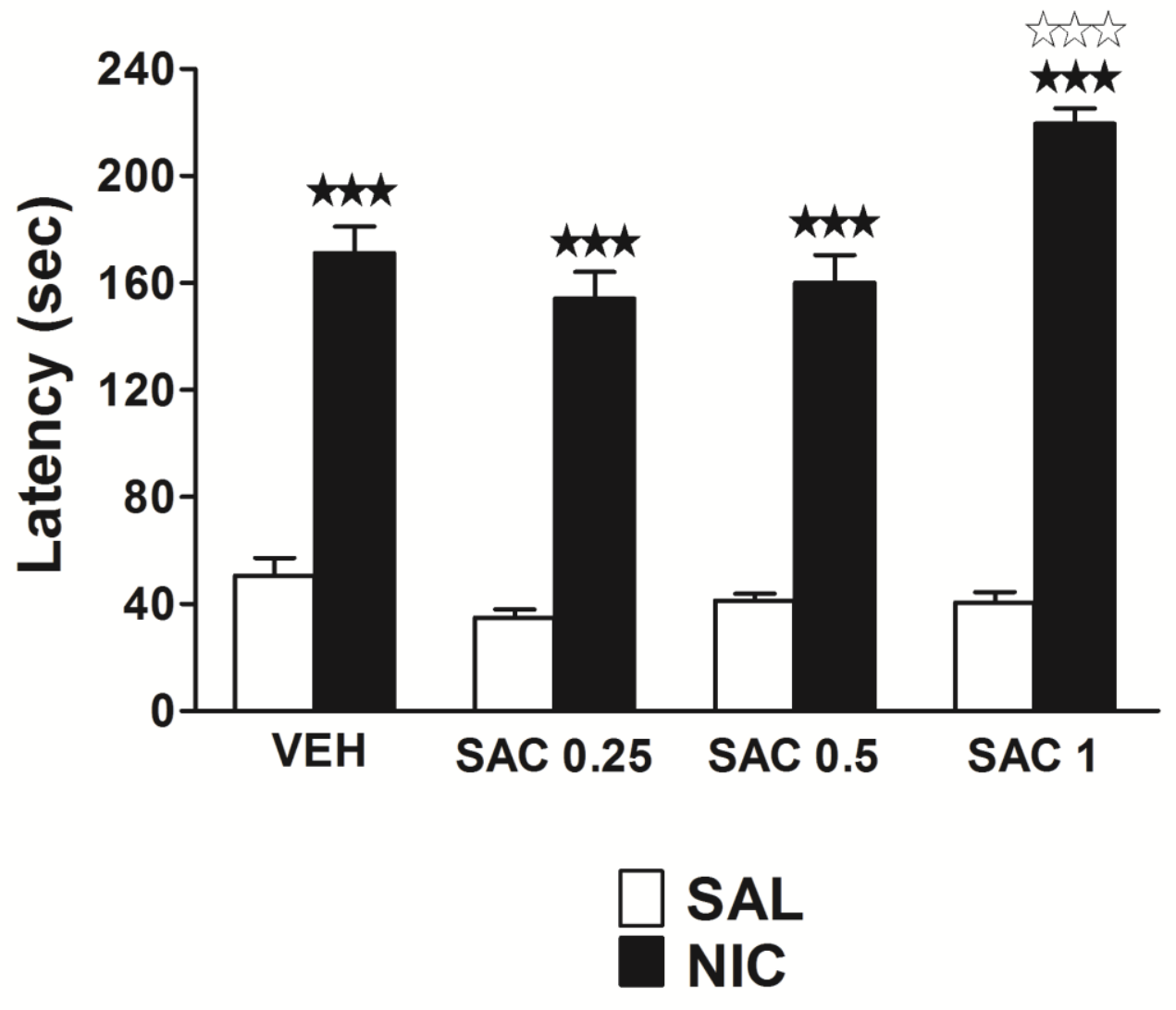

